\title{
Mapping Priority Areas for the Development of Leadership Competencies of School Principals
}

\author{
Rimantas Želvys ${ }^{1}$, Kamchat Esenova ${ }^{2}$ \\ Vilnius University, Faculty of Philosophy, Institute of Educational Sciences, Universiteto g. 9, LT-01513 Vilnius, \\ Lithuania, rimantas.zelvys@fsf.vu.It \\ 2 Al-Farabi Kazakh National University, Faculty of Philosophy and Politology, 71 Al-Farabi avenue, KZ- 050040, \\ Almaty, Kazakhstan, kamchat_esenova@mail.ru
}

\begin{abstract}
The aim of the study was to identify needs of developing competencies of Kazakhstani school principals in three domains: student achievement, involving teachers, communicating with parents. The survey included questions about the importance of responsibilities of principals and their training needs. Results indicate that principals experience a shortage of knowledge in the domains of leadership and motivation. They tend to focus on the process of teaching: financial management, human resource management and relations with external partners seem to be less important.
\end{abstract}

Keywords: leadership competencies, school principals, Masters studies in Education Management and Leadership.

\section{Introduction}

The importance of effective school leadership is highlighted in recent strategic documents of major international organizations, which are involved in the development of global education policy. In 2015 UNESCO, together with UNICEF, the World Bank, UNFPA, UNDP, UN Women and UNHCR initiated the World Education Forum which resulted in adoption of the Declaration for Education 2030. The Declaration set out a new vision for education for the next fifteen years. One of the targets defined in the Declaration is the commitment to quality education and to improving the learning outcomes, which 
requires strengthening inputs, processes and evaluation of outcomes and mechanisms to measure the progress. Authors of the declaration claim that they „will ensure that teachers and educators are empowered, adequately recruited, well-trained, professionally qualified, motivated and supported within well-resourced, efficient and effectively governed systems" (UNESCO, 2015). Therefore, in order to improve the learning outcomes of students, educational policymakers should focus on effective training and continuous professional development of the most valuable resources in education - teachers and school leaders. European Commission also highlights the quality of teachers and teacher education as one of the priorities, assuming that teachers and school leaders are central to the learning process in schools. In national education policies of most of the European countries there is an associated tendency to seek for higher levels of formal qualifications in initial teacher education, but also a trend towards a more diversified forms of professional development than were available in the past (European Commission, 2018). A number of new EU member states, including Lithuania, besides shortand long-term in-service training courses, also offer postgraduate studies in Education Management and Leadership. Other post-socialist countries recognize the necessity of developing new models of academic studies in leadership education, and Kazakhstan is one of these countries. National policy decisions in building the system of leadership training can provide useful insights for researchers interested in comparative education. Usually, the development of any new training program starts with identifying the needs of the trainees. Therefore the research question of our study was focused on the training needs of educational leaders and determined the aim of the research, namely, mapping the priority areas which should be covered in Masters study programs for a successful development of leadership competencies of school principals in Kazakhstan. The research study was initiated in order to find out which areas of leadership competencies school principals consider being most important and should be elaborated in order to create an evidence-based and student-centered model for school leadership training in the country. The novelty and originality of the research study is determined by the fact that leadership training is a relatively new phenomena in post-socialist countries which are not following the mainstream of the common European education policy. While the new EU member states are catching up with their Western counterparts and have a more or less established tradition of school leadership training, other post-socialist regions, like the Caucasus and Central Asia, are still at the initial stage of developing regular leadership training programs.

The aim of the study: to define priority areas for leadership training of school principals.

\section{The objectives of the study:}

- to review contemporary concepts of school leadership;

- to present examples of definining leadership competencies in legal acts and normative documents in different countries; 
- to clarify Kazakhstani school principals opinion about the possibilities of using leadership competencies within the school community.

The methods of the study: analysis of documents and desriptive statistics of the data received by using the multiple choice opinion questionnaire.

\section{Definitions of educational leadership and competencies of school leaders}

The concepts of leadership, management, headship, etc., in education usually overlap and are interchangeably used in different world regions and cultures. There are numerous definitions of the concept of leadership, which reflect a great variety of professional activities exercised in schools. Perhaps the most well-known traditional definitions are those of Peter Drucker that managers are doing „things right" while leaders are doing "right things", or that management is about maintenance, and leadership is about change. During the last decades, the understanding of a school leader as a change agent became a universally accepted notion and is taken for granted. However, besides being a visionary and an initiator of change, the educational leader has many other missions to accomplish. One of the most recent and explicit definitions states that „educational leadership is the professional practice of a leader (or leaders) in an administrative role(s) working with, guiding and influencing educators in a particular context toward improving learning and other educational processes in early childhood education centres, elementary, secondary and postsecondary institutions. These people are most often individuals or small teams employed as school site leaders, principals, assistant or associate administrators" (Santamaria, 2016). Therefore currently there is a commonly shared understanding that school leaders are school principals or other individuals, who are empowered to take administrative decisions and/or guide and influence other members of the staff. School leaders are primarily responsible for the effective functioning of the school; however, well-functioning school as a learning organization contributes to a better learning in classrooms. Research evidence shows that school principals are second only to classroom teachers in their influence upon student outcomes (Day, Sammons, 2014). Green (2010) points out 13 core competencies of school leadership that lead to the formation of four leadership dimensions: understanding self and others, understanding the complexity of organizational life, building bridges through relationships and engaging in leadership best practice. The research of Ross and Cozzens (2016) revealed that the five most observed core competencies of school principals were professionalism, curriculum and instruction, diversity, collaboration, and assessment. Different aspects of school leadership are also 
discussed in publications of internationally recognized authors like Sergiovanni (1992, 2006), Fullan (2011, 2012, 2018), Hargreaves and Fink (2005).

National ministries issue legal acts and normative documents defining key competencies of school leaders. Mustamin and Yasin (2012) summarize key areas of competencies described in normative documents of some selected countries:

- Ministry of Education in Malaysia defines the following competency areas: policy and decision-making, development of teaching, managing change and innovation, managing resources and operation, managing human relations, effective self-management;

- Florida Department of Education: vision, partnership with community and stakeholders, managing diversity, instructional leadership, managing learning, accountability and assessment, decision-making strategies, managing technology, managing human resources, ethical leadership;

- Ministry of Education in Indonesia: personality competencies, management competencies, entrepreneurship competencies, supervision competencies.

In the USA the Council of Chief State School Officers (2008) have identified the following competencies: visionary leadership, instructional leadership, managerial leadership, collaborative leadership, ethical leadership and political/community leadership. Minnesota Association of School Administrators (2010) pointed out similar competencies: strategic leadership, instructional leadership, managerial leadership, cultural leadership, communications leadership, school community leadership, ethical and professional leadership.

Ministry of Education and Science of the Republic of Lithuania in its 2011 version of qualification requirements for school principals defined five key general and five key managerial competencies for school principals. Key general competencies include: personal effectiveness, strategic thinking and managing change, ability to learn, managing people, cooperation and information. Key managerial competencies include: strategic management of educational organizations; managing teaching and learning; managing in-service training of the teaching staff; managing structure, processes and resources of educational organizations; managing cooperation and partnership of educational organizations (Bairašauskienè, 2017).

The review of the examples of defining leadership competencies in different countries implies that in fact it's possible to summarize all of them into four broad areas of competencies for school principals:

- Managing policy (vision and strategic planning, school improvement policy and decision-making, etc.);

- Managing people (personal effectiveness and self-management, managing the learning community, shared leadership and teambuilding, supervision and in-service training of the teaching staff, cooperation with parents, social partners and other stakeholders, ethics and professional behaviour, etc.); 
- Managing teaching and learning (instructional leadership, managing curriculum, managing diversity and change, managing student achievement, school-level accountability and assessment, etc.);

- Managing resources (entrepreneurship, school-based financial management; managing processes, structures and technologies at school, etc).

In terms of knowledge transfer, the most favourable area is the one, which relates to the management of people. Policy issues may be country-specific as different countries favour different levels of centralization and autonomy of schools, so there are different ways of interaction between national, regional and school-based policies. Curriculum contents and models of accountability and assessment may also differ as countries use different models of monitoring the education process. Countries apply different schemes of funding and grant different levels of financial autonomy to schools. On the other hand, principles of shared leadership and teambuilding,the involvement of the teaching staff in the decision-making process, cooperation and partnership with parents and other stakeholders in most of the countries, despite some cultural differences, are more or less universal.

\section{Leadership Training in Kazakhstan}

Kazakhstan has a centralised education system, with extensive central planning and a detailed system of norms. The Government plays an important role in the definition of education strategies and in the development of key initiatives. Compared to most of OECD countries, Kazakh schools have lower levels of autonomy (OECD, 2018). However, the country is implementing a series of education reforms in order to update the system of education in line with the global tendencies. Recently Kazakhstani school principals were granted a higher level of autonomy in decision-making. For example, school leaders in Kazakhstan scored higher than the OECD average in the PISA 2015 index of educational leadership (measuring the levels of principals' engagement in leadership activities), at 0.55 , compared to the OECD average of 0.01 (OECD, 2018). Many efforts are directed towards improving the overall performance of students. School principals in Kazakhstani schools are responsible for allocating students in classes, organizing support for low performing students, distributing responsibilities among teachers and organizing the learning activities. They exercise a higher level of autonomy in managing teaching resources: recruiting the teaching staff, allocating the teaching duties and dismissing teachers. Therefore they must have a sufficient level of knowledge in areas of school improvement and human resource management. However, school leaders often seem to lack the necessary leadership competencies and are not always prepared to foster school improvement. Recruitment of school principals focuses on their educational qualifications and experience rather than their leadership abilities. Few opportunities 
exist to take up professional development and most of them are disconnected from their daily practice in schools (OECD, 2015). Traditional short-term courses, which are usually called retraining courses (teachers are retrained to work as school principals), still prevail in the country. Retraining of administrative staff is mainly organized by the Republican Institute for Development of the Leading and Pedagogical Staff. Heads of regional, city and district departments of education; principals and deputy principals of comprehensive schools, preschool and out-of-school educational institutions undertake the retraining courses. In line with the Bologna process, Kazakhstani universities began to develop postgraduate courses similar to the ones existing in other Bologna countries. Academic training of school leaders started about a decade ago. First experimental leadership training programs of Masters level were launched in Al-Farabi Kazakh National University. Currently some leading higher education institutions of the country, such as Al-Farabi Kazakh National University, Academy of Public Administration under the President of Kazakhstan, Akhmet Yassawi International Kazakh-Turkish University, Abai Kazakh National Pedagogical University, are offering leadership training courses and programs (Kussainov, Želvys, Yessenova, 2019). Despite the increased interest in leadership education, until recently the training of school leaders in the country is not defined by any standards. Pre-training of school leaders seems to be not very effective as only 4 percent of the trainees later receive leadership appointments. However, there is a description of functional responsibilities of school principals, which defines the areas in which school leaders should exercise their leadership competencies. OECD experts note that systemic approach to the development of school leaders in needed. A diagnosis of the skills of school leaders can help inform the next steps in identifying professional development needs for acting and future leaders (OECD, 2015).

Currently, in Kazakhstan as well as in many other countries there are three dominant models of leadership training: short-term courses, long-term training programs and university training which usually leads to an academic award. Short-term training courses are practiced in Kazakhstan since the Soviet times. For a long period of time, such courses were the only means of training for acting school principals and pre-training or retraining of prospective candidates for the principalship. Short-term training courses can effectively provide actual information on specific topics, e g. changes in legislation or national curriculum. However, they are not sufficient for covering broad themes like human resource management, entrepreneurship or public relations in education. Kazakhstani institutions of education also participate in long-term training programs, e. g., the EU-funded TEMPUS-EDUCA project „Modernization and Development of Curricula on Pedagogy and Educational Management in the Central Asian countries“. The project lasted for three years (2012-2015) and involved ten universities from Kazakhstan, Kyrgyzstan and Tajikistan. Kazakhstan was represented by Kazakh Abai National Pedagogical University, Kyzylorda Korkyt Ata State University, Karaganda E. A. Buketov State University and Semey Shakarim State University. There were numerous seminars held in the 
premises of participating universities. They were tailored for the academic staff involved in teacher education and served as a preparation for launching postgraduate academic programs. The project resulted in development of curricula for education management training (Nikitenko, Dzhanaliev, 2014). Masters studies in Education Management, when compared with other forms of continuous professional development, have several advantages. First of all, Masters studies provide an opportunity of systemic training in key leadership areas, including research-oriented education, curriculum management, regular assessment of student achievement, etc. Secondly, school principals and teachers with graduate diploma in the field of education, who wish to continue their studies, prefer to obtain a Masters degree as it's perceived as a symbol of higher status and prestige and is usually considered as an advantage when competing for leadership positions.

Methodology. The quantitative methodology approach was chosen for the current study. The choice was based on the assumption that the main aim of the research is to get a general understanding of principals' opinions about competencies necessary for the successful leading of school and to gain primary insight for the latter more indepth investigations. When comparing with the qualitative methodology, quantitative research is more efficient in testing hypotheses (Choy, 2014; McCusker, Gunaydin, 2014). Another advantage of the quantitative methodology is that usually it's not a very much time-consuming activity, and it also allows the determination of the extent of agreement or disagreement among the respondents (Yauch, Steudel, 2003). Bearing in mind rapid development of leadership training in Kazakhstan, using quantitative methodology seemed to be the most appropriate way of clarifying the prevailing outlooks of school principals during a relatively short period of time.

The method. Opinion questionnaire with multiple choice answers was applied in the survey. Several questions were formulated in the way that respondents could choose more than one answer.

Sample and its characteristics. A pilot survey was conducted as an indirect response to the request of the OECD experts to make a diagnosis of the competencies which could help in identifying professional development needs of school leaders. 104 school principals from different regions of Kazakhstan filled the multiple choice opinion questionnaire during the academic year 2016/2017. The education level of the respondents was the following: $2 \%$ - Masters degree, 35\% - specialist higher education diploma, 49\% - Bachelor degree, $14 \%$ - other. The aim of the questionnaire was to clarify school principals' opinion about the possibilities of leading the members of the school community (students, teachers and parents) in three domains of school activities:

- Leadership in improving the student achievement;

- Leadership in teacher involvement in decision-making, school policy development and school improvement;

- Leadership in relations with parents and parent involvement; 
The questionnaire also included questions about the importance of responsibilities of school principals and the need of knowledge and skills.

Descriptive statistics was used for the data analysis.

\section{The results of a survey}

Responses to the opinion questionnaire indicate that most of the participants of the survey believe in their abilities to improve the level of student achievement, classroom teaching,the involvement of teachers and parents in the decision-making process, etc. They also assume that the assessment of the teaching quality is one of their main responsibilities. Therefore the teaching process, curriculum and academic achievements seem to be the main focus of the school policies.

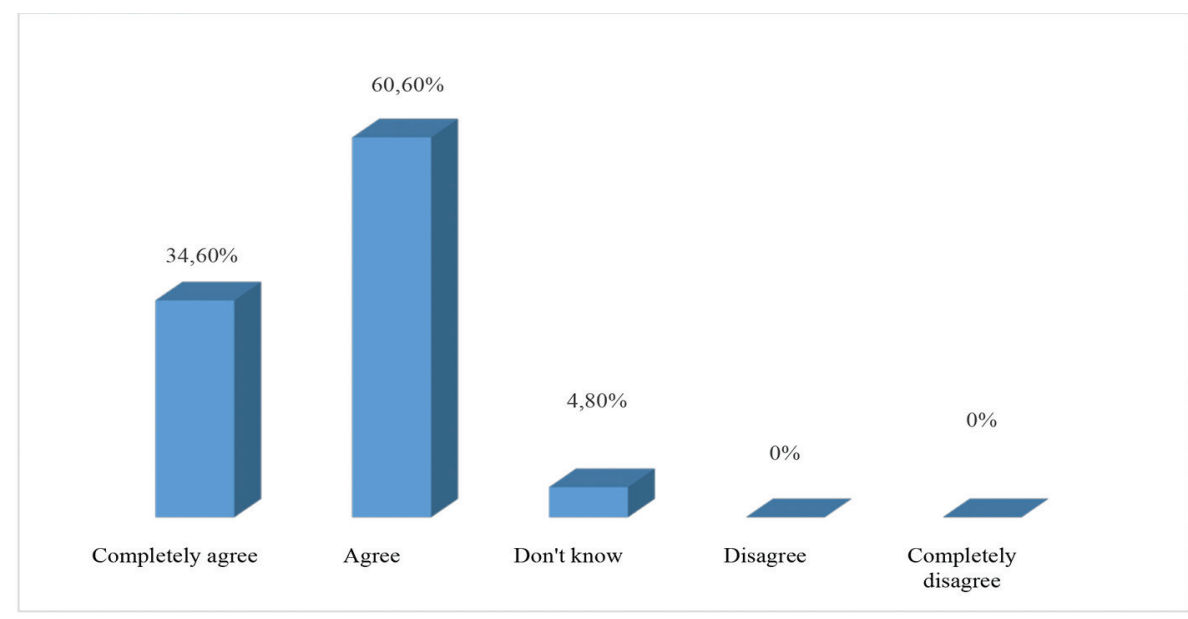

Figure 1. The opinion of principals about the assistance of teachers for the increasing the level of student achievement

More than $95 \%$ of school principals believe that they can affect student achievement by providing more active assistance to teachers. Less than five percent were not sure about that, and nobody disagreed with the statement. It seems that school principals, who participated in the survey strongly believe in their ability to assist the teachers in their educational activities and thus use the power of educational leadership for the benefit of students. 


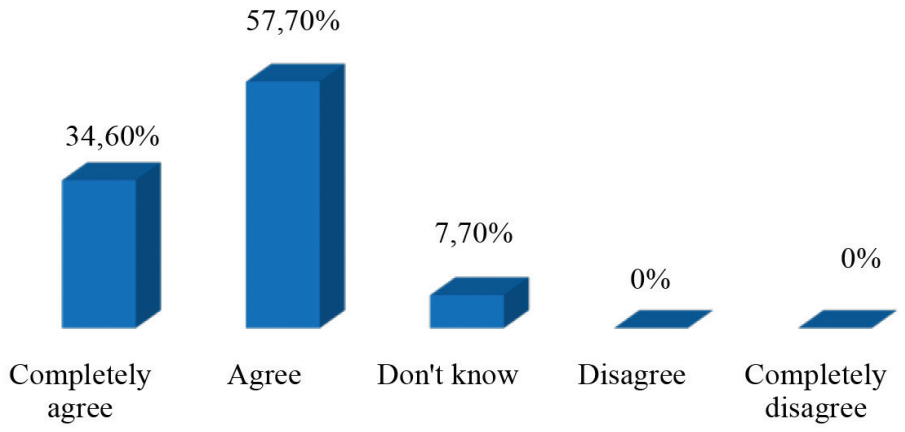

Figure 2. The opinion of principals about their powers to support all students for the improvement of their achievement

More than $90 \%$ of school principals believe they have sufficient powers to ensure that all students achieve better results in case they receive relevant support from them. Almost eight percent of respondents were not sure about that, but nobody disagreed. It seems that a strong belief in the possibilities of supporting all students can be a powerful motivating factor for school principals. One can only wonder whether the belief of possessing such exclusive powers seems to be very realistic.

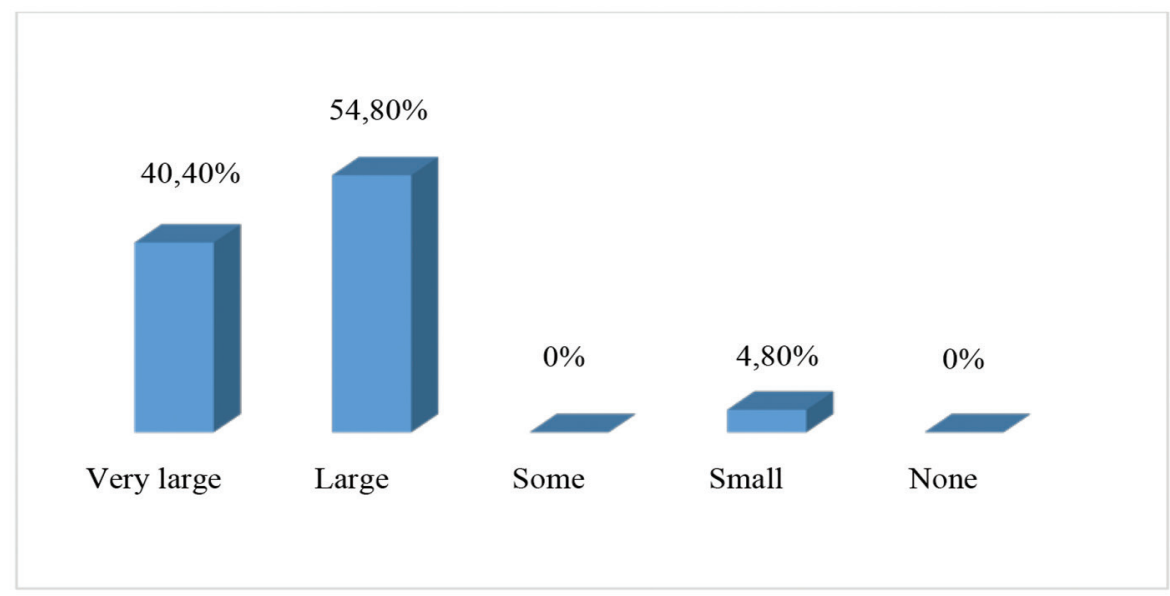

Figure 3.The opinion of principals about the ability to influence teachers in order to ensure effective classroom teaching

Less than $5 \%$ of principals are hesitant about their abilities to ensure effective classroom teaching. The rest $95 \%$ of respondents think that they can influence teachers to a large or even to a very large extent. Nobody disagreed with the statement. Here we again 
observe a surprisingly optimistic belief of school principals in their powers of making teaching in the classrooms more effective.

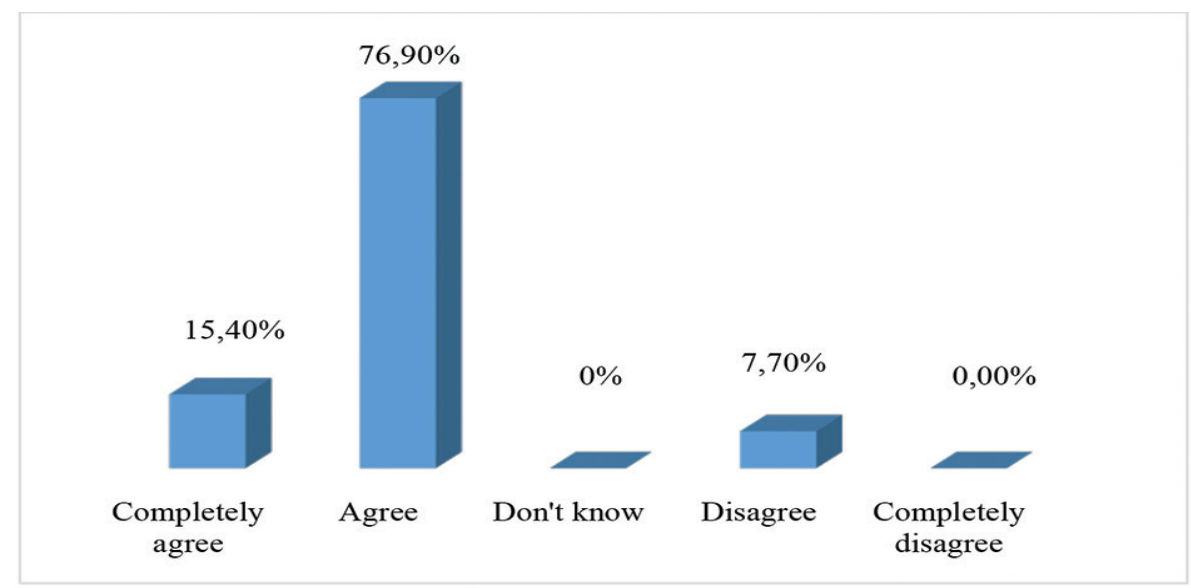

Figure 4. The opinion of principals about the contribution of teachers in the development of school policy

More than $92 \%$ of respondents believe that teachers can contribute to the development of school policy. Almost 8\% disagree with the statement. Responses indicate that Kazakhstani school principals are ready to share their responsibilities with the rest of the school staff. OECD experts also claim that formal allocation of school leadership responsibilities among several staff is a strength of Kazakh school system. Experts note that in practice, however, the distribution of responsibilities is dictated by norms and the presence of shared vision is questionable (OECD, 2018).

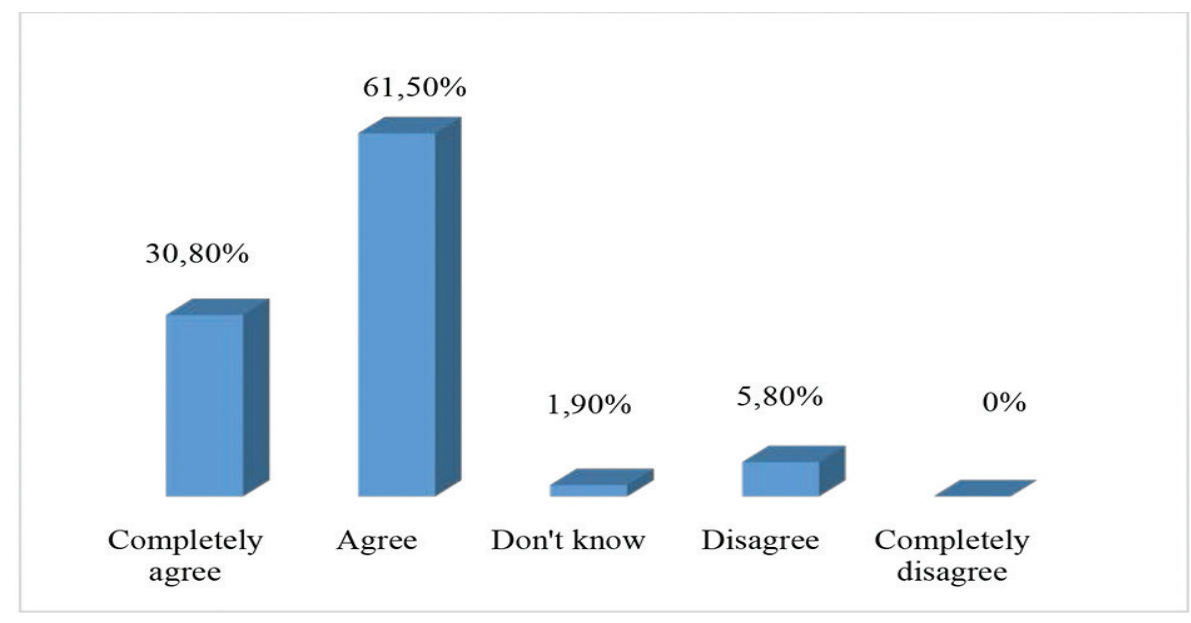

Figure 5. The opinion of principals about teacher involvement in the process of school improvement 
More than $92 \%$ of respondents agree that teachers should take part in the process of school improvement and the percentage of affirmative answers is close to that of the previous question. However, the percentage of those who completely agree with the statement is even higher than in answering the previous question, and the percentage of respondents, who disagree with the statement, is lower. Seemingly, responses demonstrate a strong determination of school principals to involve teachers in school improvement activities.

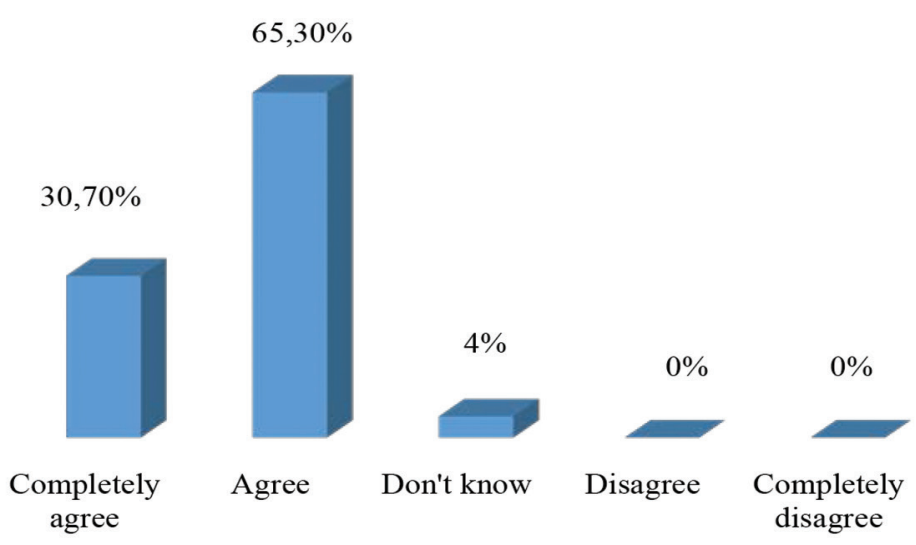

Figure 6. The opinion of principals about the involvement of the school staff in the decision-making process

$96 \%$ of respondents agree that one of the priorities of school principal should be involvement of the school staff in the decision-making process. Only $4 \%$ don't know whether this should be the priority task of school leadership.

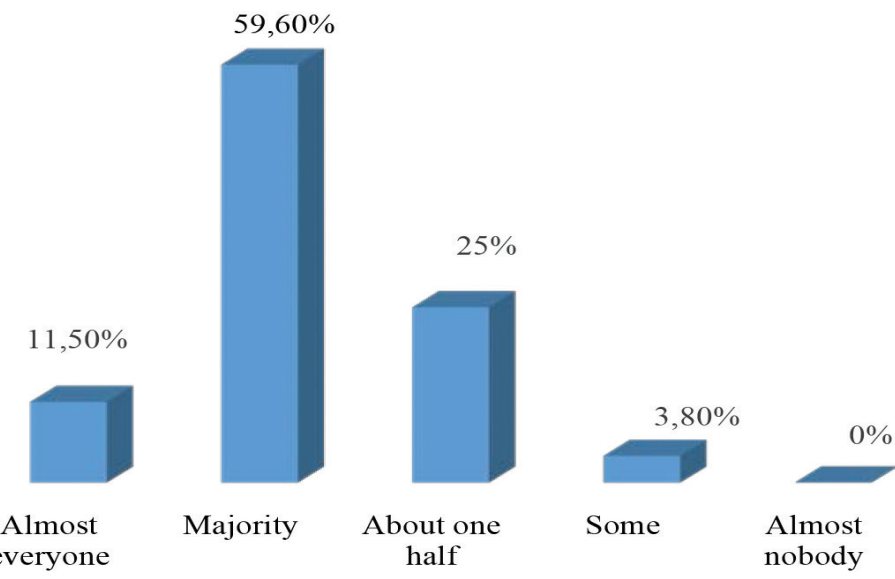

Figure 7. The opinion of principals about the parents' will to receive information about their childrens' life in school 
Almost $60 \%$ of respondents claim that majority of parents are willing to receive information about their childrens' life in school. More than ten percent noted the interest of almost everyone. One quarter of school principals think that behavior and comfort of their children interests about one half of the parents, and few school principals that interest is limited to just some parents in the classroom.

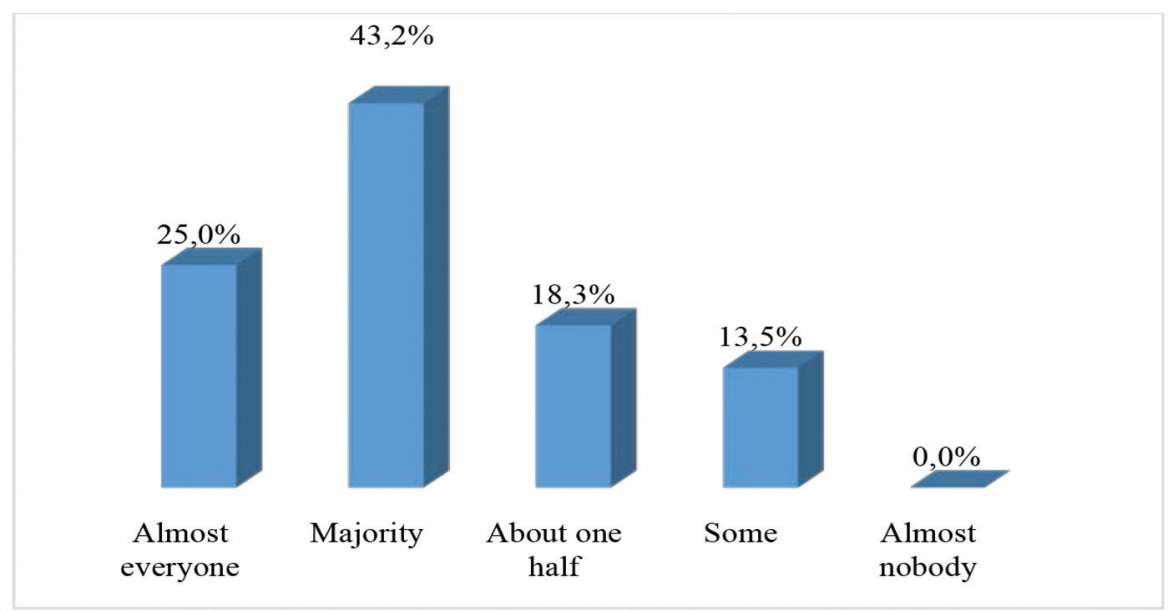

Figure 8. The opinion of principals about the interest of parents in academic achievement of their children

The results indicate that in most schools a majority of parents show interest in academic achievements of their children - almost seventy percent. More than $18 \%$ of respondents replied that about one half of the parents are interested in their childrens' academic success, and more than $13 \%$ noticed interest of some of the parents.

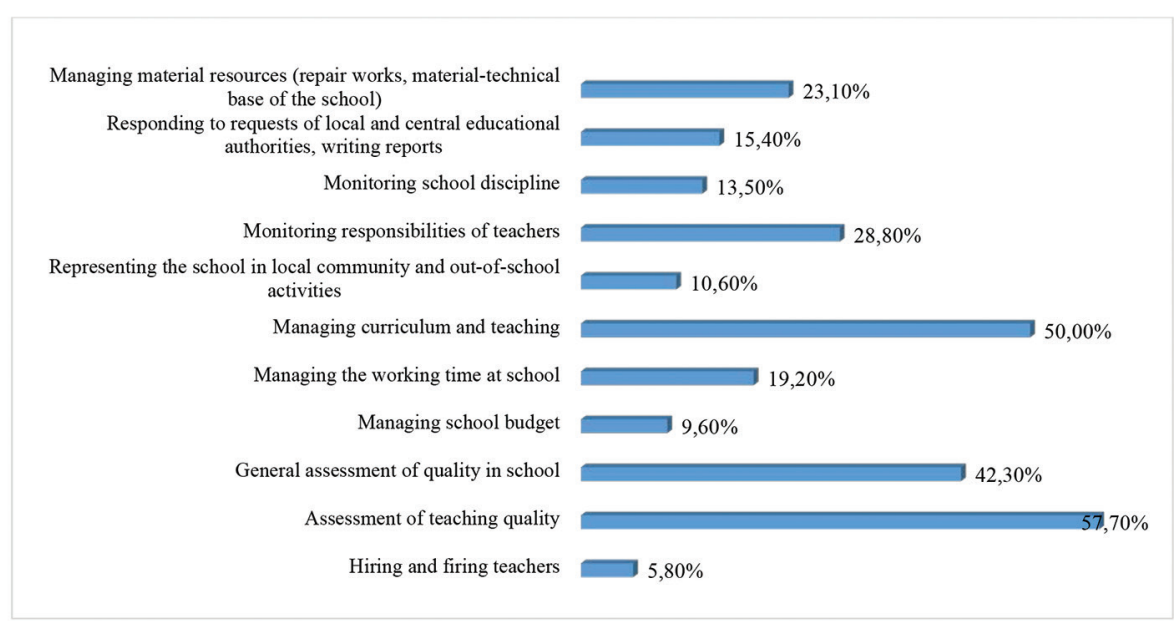

Figure 9. The opinion of principals about the importance of their responsibilities (respondents could choose more than one answer) 
The most important responsibility, according to the respondents, is the assessment of teaching quality. More than one half of school principals listed it as one of the priorities. Half of the respondents mentioned the responsibility of managing curriculum and teaching, and more than $42 \%$ - general assessment of quality in school. Monitoring the responsibilities of teachers is in the fourth place of the list. In general, we may conclude that managing curriculum, teaching and quality of schooling are top priorities for Kazakhstani school principals. Managing material resources and school budget stand lower on the list of priorities. It's interesting to note that relations with external environment - responding to requests of local and central educational authorities, writing reports, as well as representing the school in the local community and out-of-school activities - seem to be chosen by the respondents as the least important responsibilities. School principals also do not consider the duty of hiring and firing teachers as one of the important responsibilities.

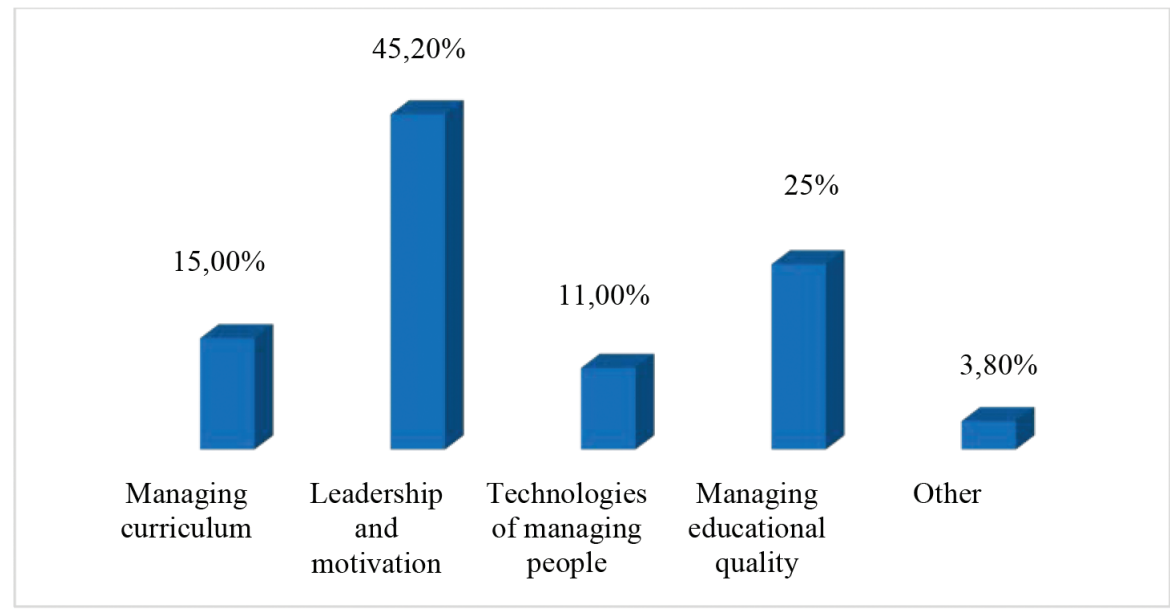

Figure 10. The opinion of principals about the areas where they experience shortage of skills and knowledge

More than $45 \%$ of respondents claim to experience a shortage of skills and knowledge in the area of leadership and motivation. 25\% would like to improve their skills and knowledge in managing educational quality. $15 \%$ of school principals prefer to update their knowledge and skills of managing curriculum, and only $11 \%$ would like to master technologies of managing people. 


\section{Discussion and conclusions}

A variety of definitions of educational leadership can be found in literature; however, currently it seems to be a commonly shared understanding that educational leaders are school principals or other individuals, who are empowered to take administrative decisions and/or guide and influence other members of the staff. Effective leadership implies the acquisition of necessary competencies. There are numerous lists of educational leadership or/and management competencies, which may serve different purposes. They are elaborated by ministries as a set of legal requirements, by professional associations as a tool for peer evaluation, or by academicians as landmarks for postgraduate leadership training. However, these lists are rather similar in contents and can be reduced to four main areas of activities: managing policy, managing people, managing teaching and learning, and managing resources. The most prospective group of competencies for the purpose of educational borrowing and learning from each other is the domain of managing people. Patterns of leadership in domains of policies, curriculum and principles of resource supply are more difficult to follow as they may be different in different countries. Managing student achievement may also be attributed to the group of competencies of managing people, because school leaders mainly affect student achievement indirectly, by creating a favourable learning environment for students, motivating teachers and encouraging the involvement of parents. The development of relevant competencies may take place in different forms of professional training, including short-term courses, longterm programs and postgraduate studies. Postgraduate studies at Masters level seem to be most appropriate as they bear the most systematic and sustainable character, contribute to obtaining a higher professional status and prestige and can serve as an advantage when applying for a leadership position on a competitive basis. As preparation for introducing a postgraduate study program, a pilot opinion survey was initiated in order to find out which domains of school leadership seem to be most important to school principals in Kazakhstan. Answers to the questions of the opinion survey demonstrate an overly optimistic view of school principals about the possibilities of leading school communities and improving different aspects of the school life. We can only guess whether school principals projected an idealistic view of themselves, or they really perceive themselves as very influential in their own organizations. Results of the survey correspond with findings of other researchers, who also note high level of self-confidence observed among school principals. School heads believe that they have sufficient level of competencies for developing a school vision, determining strategic directions of school policies, developing cooperation with parents and social partners (Navickaite, 2012). Research, conducted by Tapa (2016), showed that principals claimed themselves to be more competent at leadership roles and also pointed out higher importance of all their leadership competencies in the future than those of school teachers and supervisors. Anyway, if school principals actually believe that they can change things for the better in their schools, it's 
a great motivating force. However, our respondents claim that they mainly experience the shortage of skills and knowledge in the domains of leadership and motivation. Other studies also reveal, that, despite a high level of self-confidence, school principals experience lack of managerial skills and knowledge (Mečkauskiené, Želvys, 2012). We have noted already that short-term courses, which can be effective when getting acquainted with new legislation or curriculum changes, will not be sufficient as the skills of leading and motivating people can be mastered over a longer period of time. Therefore long-term leadership training, most probably Masters studies in Education Leadership and Management, could suit better for filling the knowledge gap. Interestingly, in defining the most important areas of responsibility the school principals tend to focus on teaching: assessment of teaching quality, managing curriculum and teaching, and assessment of the quality of schooling in general. Functions of presenting the school to local community and educational authorities seem to be less important. It seems that time for mastering principles of marketing, promotion and public relations is still to come. Surprisingly, domains of management, usually highlighted prioritized in other surveys (Mestry, 2004; Mečkauskiené, Želvys, 2012) - financial management (managing school budget) and human resource management (hiring and firing teachers) - appear to be less important for our respondents. Perhaps the most surprising finding was that school principals did not consider relations with external environment - local communities and educational authorities - as top priority responsibilities. The findings apparently reflect the specificity of the country which needs further investigation. Results of the survey provide some new insights and identification of priority areas contributes to further development of a model of training for school principals in the country.

\section{References}

Bairašauskienė, L. (2017). Bendrojo ugdymo mokyklų vadovų kompetencijų reikšmingumas. Socialinis ugdymas, 46(2), 89-102.

Choy, L. T. (2014). The Strengths and Weaknesses of Research Methodology: Comparison

and Complimentary between Qualitative and Quantitative Approaches. IOSR Journal of Humanities and Social Sciences, 19(4), 99-104.

Council of Chief State School Officers. (2008). Interstate School Leaders Licensure Consortium:

Standards for School Leaders. Retrieved May 15, 2019 from http://www.fldoe.org/core/fileparse. php/7566/urlt/0075311-orgstand.pdf.

Day, C., Sammons, P. (2014). Successful School Leadership. Reading: Education Development Trust. European Commission. (2018). European Ideas for Better Learning: The Governance of School Education Systems. Brussells: European Commission.

Fullan, M. (2011). Change Leader: Learning to Do What Matters Most. San Francisco: Jossey-Bass. Fullan, M. (2012). Leading In a Culture of Change. San Francisco: Jossey-Bass. 
Fullan, M. (2018). Nuance: Why Some Leaders Succeed and Others Fail. Thousand Oaks, CA: Corwin. Green, R. L. (2010). The Four Dimensions of Principal Leadership: A Framework for Leading 21st Century Schools. Boston: Allyn \& Bacon.

Hargreaves, A., Fink, D. (2005). Sustainable Leadership. San Francisco: Jossey-Bass.

Kussainov, A., Želvys, R., Yessenova, K. (2019). Realities of Training of Education Managers in Kazakhstan. Journal of Educational Sciences, 58(1), 58-66.

McCusker, K., Gunaydin, S. (2014). Research Using Qualitative, Quantitative or Mixed Methods and Choice Based on the Research. Perfusion, 30(7), 537-542.

Mečkauskienè, R., Želvys, R. (2012). Mokyklų vadovų požiūrio ị švietimo sisteminius pokyčius dinamika. Acta Paedagogica Vilnensia, 29, 22-34.

Mestry, R. (2004). Financial Accountability: The Principal or the School Governing Body? South African Journal of Education, 24(2), 126-132.

Minesota Association of School Administrators. (2010). The Evaluation of Minesota's School Principals. Retrieved May 14, 2019 from: https://peersolutions-usa.com/wp-content/uploads/ Association-Model.pdf.

Mustamin, M., Yasin, M. A. (2012). The Competence of School Principals: What Kind of Need Competence for School Success? Journal of Education and Learning, 6(1), 33-42.

Navickaitė, J. (2012). Mokyklos vadovo lyderystė vykstančių švietimo pokyčių kontekste. Acta Paedagogica Vilnensia, 29, 35-46.

Nikitenko, N. V., Dzhanaliev, A. F. (2014). Collected Teaching Materials (TM) of Disciplines and Other Methodical Documents. TEMPUS - EDUCA Project „Modernization and Development of Curricula on Pedagogy and Educational Management in the Central Asian Countries. Bishkek: Education Network Association.

OECD. (2015). OECD Reviews of School Resources: Kazakhstan 2015. Paris: OECD Publishing.

OECD. (2018). Education Policy Outlook: Kazakhstan. Retrieved May 14, 2019 from: http://www. oecd.org/education/Education-Policy-Outlook-Country-Profile-Kazakhstan-2018.pdf.

Ross, D. J., Cozzens, J. A. (2016). The Principalship: Essential Core Competencies for Instructional Leadership and Its Impact on School Climate. Journal of Education and Training Studies, 4(9), 162-176.

Santamaria, L. J. (2016). Theories of Educational Leadership. Oxford: Oxford University Press. Retrieved May 15, 2019 from: http://www.oxfordbibliographies.com/view/ document/obo9780199756810/obo-9780199756810-0153.xml.

Sergiovanni, T. J. (1992) Moral Leadership: Getting to the Heart of School Improvement. San francisco: Jossey-Bass.

Sergiovanni, T. J. (2006) Rethinking Leadership: A Collection of Articles. Thousand Oaks, CA: Corwin. Tapa, K. B. (2016) Present and Importance Levels Leadership Competencies of Principals in Nepalese Schools. Journal of Advanced Academic Research, 3(1), 111-122.

UNESCO. (2015) Education 2030. Incheon Declaration and Framework for Action for the Implementation of Sustainable Development Goal 4: „Towards Inclusive and Equitable Quality Education and Lifelong Learning for All“. Paris: UNESCO. 
Yauch, C. A., Steudel, H. J. (2003) Complementary Use of Qualitative and Quantitative Cultural Assessment Methods. Organizational Research Methods, 6(4), 465-481.

\title{
Mokyklų vadovų lyderystès kompetencijų prioritetinių tobulinimo sričiu nustatymas
}

\author{
Rimantas Želvys ${ }^{1}$, Kamchat Esenova² \\ Vilniaus universitetas, Filosofijos fakultetas, Ugdymo mokslų institutas, Universiteto g. 9, LT-01513 Vilnius, \\ Lietuva, rimantas.zelvys@fsf.vu.lt \\ 2 Al-Farabi Kazachijos nacionalinis universitetas, Filosofijos ir politologijos fakultetas, Al-Farabi pr. 71, KZ-050040, \\ Almata, Kazachstanas, kamchat_esenova@mail.ru
}

\section{Santrauka}

Norint pagerinti mokinių pasiekimus, reikètų skirti didesnį dėmesį mokytojų ir mokyklų lyderių mokymui bei nuolatiniam profesiniam tobulejimui. Šio tyrimo tikslas buvo nustatyti prioritetines Kazachijos mokyklų vadovų lyderystės kompetencijų tobulinimo sritis. Atlikta analizè parodé, kad perspektyviausiomis sritimis gerosios patirties perèmimo ir bendro mokymosi prasme laikytinos vadovavimo žmonèms kompetencijos, o tinkamiausia rengimo forma - magistrantūros studijos. Norint išsiaiškinti mokyklų vadovų nuomonę apie lyderystės mokyklos bendruomeneje galimybes, jiems buvo pateiktas klausimynas su pasirenkamais atsakymų variantais. Klausimynas apėmė tris mokyklos veiklos sritis: lyderystę gerinant mokinių pasiekimus; lyderystę ịtraukiant mokytojus ị sprendimų priėmimo, mokyklos tobulinimo ir politikos formavimo procesus; lyderystę santykiuose su tèvais. Taip pat buvo klausiama, kokios vadovų atsakomybės sritys laikytinos svarbiausiomis ir kokių žinių bei igūdžių tiriamieji labiausiai pasigenda. Rezultatai parodè, kad tiriamųjų požiūris ị galimybes tapti mokyklų bendruomenių lyderiais ir pagerinti ̣̂vairius mokyklinės veiklos aspektus yra per daug optimistinis. Kita vertus, mokyklų vadovai teigé, kad jiems labiausiai trūksta žinių bei igūdžių lyderystès ir motyvavimo srityse. Vertindami svarbiausias vadovų atsakomybės sritis, tiriamieji pagrindinị dèmesị buvo linkę skirti ugdymo procesui: mokymo kokybės vertinimui, mokymosi ir ugdymo turinio vadybai, bendram mokyklos veiklos kokybės vertinimui. Finansų vadyba, žmogiškųjų išteklių vadyba ir santykiai su išorine aplinka tiriamiesiems pasirodè ne tokios svarbios sritys.

Esminiai žodžiai: lyderystès kompetencijos, mokyklų vadovai, švietimo vadyba ir lyderyste, magistrantūros studijos. 